\title{
Adherence of Fusobacterium necrophorum to bovine ruminal cells
}

\author{
M. KANOE and K. IWAKI
}

Department of Veterinary Microbiology, Faculty of Agriculture, Yamaguchi University, 753 Yamaguchi-shi, Japan

\begin{abstract}
Summary. The adherence of Fusobacterium necrophorum to the surface of bovine ruminal epithelial cells was paralleled by the organism's haemagglutinating ability. Treatment of the bacterial cells with haemagglutinin antiserum caused a reduction in the degree of attachment. The purified haemagglutinin became bound to the membranes of ruminal epithelial cells but lost its adherence when pre-incubated with haemagglutinin antiserum. These findings suggest that the adherence of $F$. necrophorum to the membrane of the ruminal cells is mediated by haemagglutinin.
\end{abstract}

\section{Introduction}

Bacterial adherence to mucosal surfaces is recognised as an important early step in infection (McNeish et al., 1975; Beachey, 1981). The ability of certain pathogens to attach themselves to mammalian cells appears to be mediated by bacterial pili, haemagglutinin (HG) and capsule (Burrows et al., 1976; Wilson and Collier, 1976; Fader et al., 1979; Tajima et al., 1985). It is thought that Fusobacterium necrophorum colonises the bovine ruminal epithelium, sometimes penetrating into the venous system and thereby infecting the abdominal organs (Kanoe et al., 1984).

Little is known, however, about the mechanism of adherence and mucosal colonisation. Previously we described the purification of $F$. necrophorum $\mathrm{HG}$ (Nagai et al., 1984). In this paper we report the adherence of $F$. necrophorum to bovine ruminal epithelial cells and the role played by $\mathrm{HG}$.

\section{Materials and methods}

\section{Bacterial strains and culture}

Four strains were used in this study. Two (VPI 2891 and 118) were kindly supplied by Dr Shinjo, Miyazaki University and one (S-45) by Dr Miwatani, Osaka University. Strain "Goat" was isolated from a caprine oral abscess. As described by Nagai et al. (1984), bacteria were cultured at $37^{\circ} \mathrm{C}$ for $24 \mathrm{~h}$ in modified heart infusion broth supplemented with cysteine monohydrochloride $0 \cdot 1 \%$ and ascorbic acid $0 \cdot 1 \%$. They were then collected by

Received 27 Jan. 1986; accepted 6 May 1986. centrifugation, washed three times with phosphate buf-

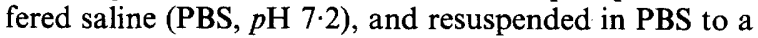
concentration of $10^{7}$ cells $/ \mathrm{ml}$.

\section{Preparation of cells}

Bovine ruminal and reticular tissue was obtained from an abattoir. Epithelial cells, collected by gentle brushing with a toothbrush, were washed three times with PBS and resuspended in the buffer to a density of $10^{5} \mathrm{cells} / \mathrm{ml}$.

\section{Adherence assay}

The epithelial cell suspension $(1.0 \mathrm{ml})$ and the bacterial cell suspension $(0.3 \mathrm{ml})$ were mixed and incubated at $37^{\circ} \mathrm{C}$ for $1 \mathrm{~h}$ in a water bath. The mixture was then lightly centrifuged and resuspended three times in PBS to remove unattached bacteria. The final sediment was resuspended in $1.0 \mathrm{ml}$ of PBS and one drop of the suspension was smeared over a glass slide. The smear was dried, fixed with methanol $95 \% \mathrm{v} / \mathrm{v}$ for $5 \mathrm{~min}$, washed, and stained with Giemsa's stain. It was then examined by light microscopy $(\times 400)$. Usually 30 cells/slide were studied; the proportion of cells with bacteria attached to the surface and the number of bacteria/cell were counted.

\section{Haemagglutination test}

The method was as described previously (Nagai et al., 1984). Briefly, the bacterial suspension $(50 \mu \mathrm{l})$ was diluted serially in doubling dilutions in the wells of a plastic tray. An equal volume of suspension $(1.0 \%)$ of chicken RBC was added to each well. After incubation at $37^{\circ} \mathrm{C}$ for 30 $\mathrm{min}$ and room temperature for $1 \mathrm{~h}$ the test was read, the titre being indicated by the highest dilution showing complete haemagglutination. 


\section{Preparation of $H G$ and $H G$ antiserum}

HG (Nagai et al., 1984) was prepared as follows. To 5 $\mathrm{ml}$ of the bacterial cell suspension $\left(10^{7}\right.$ cells $\left./ \mathrm{ml}\right), 0 \cdot 1 \mathrm{~g}$ of trypsin ( 1 in 250; Difco Laboratories, Detroit) was added and the mixture was held at $37^{\circ} \mathrm{C}$ for $1 \mathrm{~h}$. The trypsin was removed by washing twice with a mixture of $0.15 \mathrm{M} \mathrm{NaCl}$ and $10 \mathrm{~mm}$ Tris (hydroxymethyl) aminomethane hydrochloride buffer at $p \mathrm{H} \mathrm{7.0}$ (TBS). The cells were resuspended in TBS containing cysteine $\mathrm{HCl} 2 \%$ and ascorbic acid $2 \%$ before being incubated in a water bath at $37^{\circ} \mathrm{C}$ for $1 \mathrm{~h}$ and then disrupted with a Super Sonic Vibrator (VR 150 P, Tomy Seiko Co., Tokyo) for 5 min with 30-s bursts separated by intervals of $2 \mathrm{~min}$. The suspension was centrifuged at $10000 \mathrm{~g}$ for $30 \mathrm{~min}$ at $4{ }^{\circ} \mathrm{C}$ and the supernate filtered through a membrane filter (Millipore Corp., Bedford, MA, USA) with a pore diameter of 0.6 $\mu \mathrm{m}$. The filtrate was then purified by Sephadex G-100 (Pharmacia, Uppsala, Sweden) column chromatography. The purified HG had a protein content of $40 \mu \mathrm{g} / \mathrm{ml}$. HG antiserum was prepared in rabbits by four intramuscular injections $(1.0 \mathrm{ml})$, at weekly intervals, of purified $\mathrm{HG}$ emulsified with an equal volume of Freund's complete adjuvant. Serum was collected one week after the final injection and stored at $-20^{\circ} \mathrm{C}$.

\section{Adherence inhibition test}

Bacterial suspension $\left(50 \mu \mathrm{l} ; 10^{7}\right.$ organisms $\left./ \mathrm{ml}\right)$ was added to an equal volume of the homologous $\mathrm{HG}$ antiserum (diluted 1 in 10 in PBS). After incubation at $37^{\circ} \mathrm{C}$ for $30 \mathrm{~min}$, the mixture was added to the epithelialcell suspension $\left(10^{5}\right.$ cells $\left./ \mathrm{ml}\right)$, allowed to stand at $37^{\circ} \mathrm{C}$ for $30 \mathrm{~min}$, and washed with PBS. The sediment was resuspended in $0.2 \mathrm{ml}$ of PBS and one drop was smeared over a glass slide. As described above, the smear was dried, fixed, stained, and examined by light microscopy. Inhibition was expressed as the ratio of the number of antiserum-treated bacteria/cell to the number of untreated bacteria/cell.

\section{Pretreatment of bovine epithelial cells}

Trypsin, pepsin (Worthington Diagnostic Systems Inc., Freehold, NJ, USA) and lipase (Wako Chemicals, Tokyo) were used. Cell suspension $\left(1 \mathrm{ml} ; 10^{5} \mathrm{cells} / \mathrm{ml}\right)$ was mixed with $2 \mathrm{ml}$ of the pretreatment solution $(0.5 \mu \mathrm{g} / \mathrm{ml})$ and allowed to stand at $37^{\circ} \mathrm{C}$ for $30 \mathrm{~min}$. The cells were washed and resuspended in PBS. Bacterial adherence was then assessed as described above.

\section{Immunofluorescence}

The epithelial cell suspension $(1 \mathrm{ml})$ was mixed with 2 $\mathrm{ml}$ of the purified $\mathrm{HG}$, incubated at $37^{\circ} \mathrm{C}$ for $1 \mathrm{~h}$, washed with PBS, resuspended in a small volume of PBS, and smeared on a glass slide. The smear was dried, fixed with acetone for $10 \mathrm{~min}$, and exposed to a 1 in 160 dilution of homologous $\mathrm{HG}$ antiserum at $37^{\circ} \mathrm{C}$ for $20 \mathrm{~min}$. After washing it was exposed to a 1 in 40 dilution of fluorescein isothiocyanate-conjugated goat antiserum to rabbit IgG at $37^{\circ} \mathrm{C}$ for $1 \mathrm{~h}$. After washing with PBS, the cells were examined by fluorescence microscopy. In addition, the purified HG $(2 \mathrm{ml})$ was pre-incubated with the homologous antiserum $(2 \mathrm{ml})$ at $37^{\circ} \mathrm{C}$ for $1 \mathrm{~h}$. The mixture $(2$ $\mathrm{ml}$ ) was then employed in the immunofluorescence study as mentioned above.

\section{Scanning electronmicroscopy}

The epithelial and bacterial cell suspensions were mixed and incubated at $37^{\circ} \mathrm{C}$ for $1 \mathrm{~h}$. The mixture was then fixed in glutaraldehyde $2 \%$ in $0.1 \mathrm{M}$ cacodylate buffer, $p \mathrm{H} 7 \cdot 2$, dehydrated in a critical point apparatus (JFC-110; Japan Electron Optics, Tokyo) and, after a gold evaporation step, examined with a scanning electronmicroscope (JSM-25SIII; Japan Electron Optics, Tokyo) at an operating voltage of $25 \mathrm{kV}$.

\section{Statistical analysis}

Statistical significance among means was determined by the $\chi^{2}$-square test. A p-value of 0.05 or less was reported as significant.

\section{Results}

\section{Adherence and haemagglutinability}

All four strains of $F$. necrophorum showed adherence to the surface of bovine ruminal cells and three of them possessed haemagglutinating activity. As shown in table I, strains VPI 2891 and Goat had a strong affinity for the cell surface $(p<0.01)$ and showed a high haemagglutinating activity, whereas strains S-45 and 118 adhered less well, and demonstrated little or no haemagglutinating activity. Attachment of the strains to reticular epithelial cells was similar to that of ruminal cells. Strain VPI 2891 was employed in the following tests.

Table I. The haemagglutinability of $F$. necrophorum and adherence to bovine ruminal cells

\begin{tabular}{lcr}
$\begin{array}{l}\text { F. necrophorum } \\
\text { strain }\end{array}$ & $\begin{array}{c}\text { Mean number of adherent } \\
\text { bacteria/cell (SD) }\end{array}$ & $\begin{array}{r}\text { Haemagglutination } \\
\text { titre }\end{array}$ \\
\hline VPI 2891 & $16 \cdot 1(1 \cdot 2)^{*}$ & 128 \\
S-45 & $5 \cdot 0(0 \cdot 8)$ & 0 \\
118 & $7 \cdot 4(1 \cdot 2)$ & 8 \\
Goat & $16 \cdot 5(1 \cdot 7)^{*}$ & 64 \\
\hline
\end{tabular}

$\mathrm{SD}=$ standard deviation of triplicate determinations. * = Significantly different $(p<0 \cdot 01)$ from the lower values. 


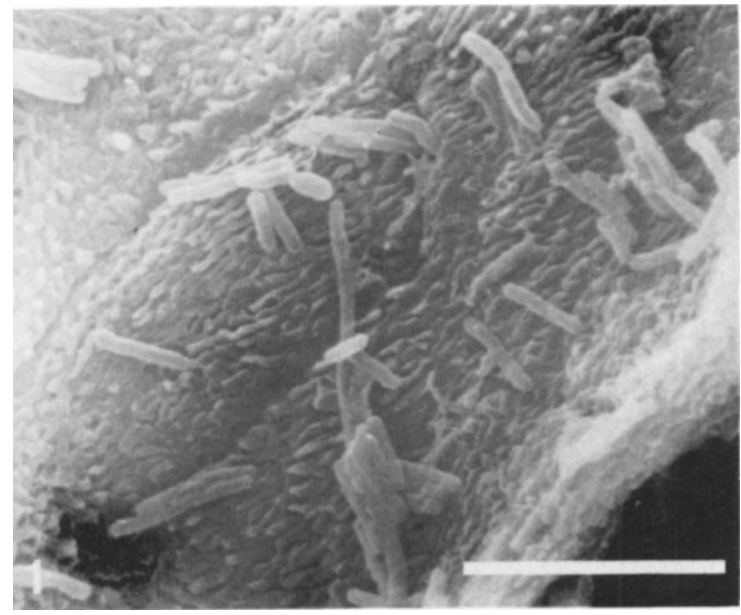

Fig. 1. Scanning electronmicrograph of bovine ruminal epithelial cells with adherent $F$. necrophorum strain VPI 2891. Bar indicates $5 \mu \mathrm{m}$.

\section{Scanning electronmicroscopy}

The fusobacteria attached themselves to the surface of the ruminal epithelial cells at $37^{\circ} \mathrm{C}$ (fig. 1) but did not become surrounded by microvilli of the cell membrane.

\section{Adherence inhibition}

Adherence was strongly inhibited by homologous HG antiserum in a dose-dependent manner. Normal rabbit serum had a similar but weaker inhibitory effect (table II).

\section{Immunofluorescence}

Fluorescence specific for the HG was demonstrated on the surface of HG-treated bovine rumi-

Table II. Inhibition of adherence of $F$. necrophorum by homologous haemagglutinin antiserum

\begin{tabular}{lccc}
\hline \multicolumn{1}{c}{ Antiserum } & $\begin{array}{c}\text { Antiserum } \\
\text { diluted } 1 \text { in }\end{array}$ & $\begin{array}{c}\text { Mean number of adherent } \\
\text { bacteria/cell (SD) }\end{array}$ & $\begin{array}{c}\text { Inhibition of } \\
\text { adherence by HG } \\
\text { antiserum* }\end{array}$ \\
\hline Control (none) & $\ldots$ & $40 \cdot 9(2 \cdot 7)$ & 100 \\
F. necrophorum & 5 & $3 \cdot 9(0 \cdot 3)$ & 9 \\
haemagglutinin antiserum & 10 & $13 \cdot 9(0 \cdot 3)$ & 34 \\
& 50 & $20 \cdot 6(0 \cdot 8)$ & 51 \\
Normal rabbit serum & 5 & $21 \cdot 2(0 \cdot 6)$ & 53 \\
& 10 & $27 \cdot 6(0 \cdot 6)$ & 98 \\
& 50 & $36 \cdot 6(0 \cdot 5)$ & 90 \\
\hline
\end{tabular}

$\mathrm{SD}=$ as in table I.

* Number of antiserum-treated bacteria/cell Number of untreated bacteria/cell

Table III. Inhibition of adherence by pretreatment of bovine ruminal cells

\begin{tabular}{lcc}
\hline \multicolumn{1}{c}{ Enzyme } & $\begin{array}{c}\text { Number of adherent } \\
\text { bacteria/cell (SD) }\end{array}$ & $\begin{array}{c}\text { Inhibition of adherence } \\
\text { by pretreatment* }\end{array}$ \\
\hline None (control) & $56 \cdot 7(0 \cdot 6)$ & 100 \\
Pepsin $0.5 \mathrm{mg} / \mathrm{ml}$ & $28 \cdot 5(2 \cdot 7) \dagger$ & $50 \cdot 3$ \\
Trypsin $0.5 \mathrm{mg} / \mathrm{ml}$ & $37 \cdot 8(3 \cdot 5) \dagger$ & 66.7 \\
Lipase $0.5 \mathrm{mg} / \mathrm{ml}$ & $49 \cdot 1(2 \cdot 8)$ & 86.6 \\
\hline
\end{tabular}

$\mathrm{SD}=$ as in table $\mathrm{I}$.

* $\frac{\text { Number of pretreated bacteria/cell }}{\text { Number of untreated bacteria/cell }} \times 100$.

$\dagger$ Significantly different $(p<0.01)$ from the control. 

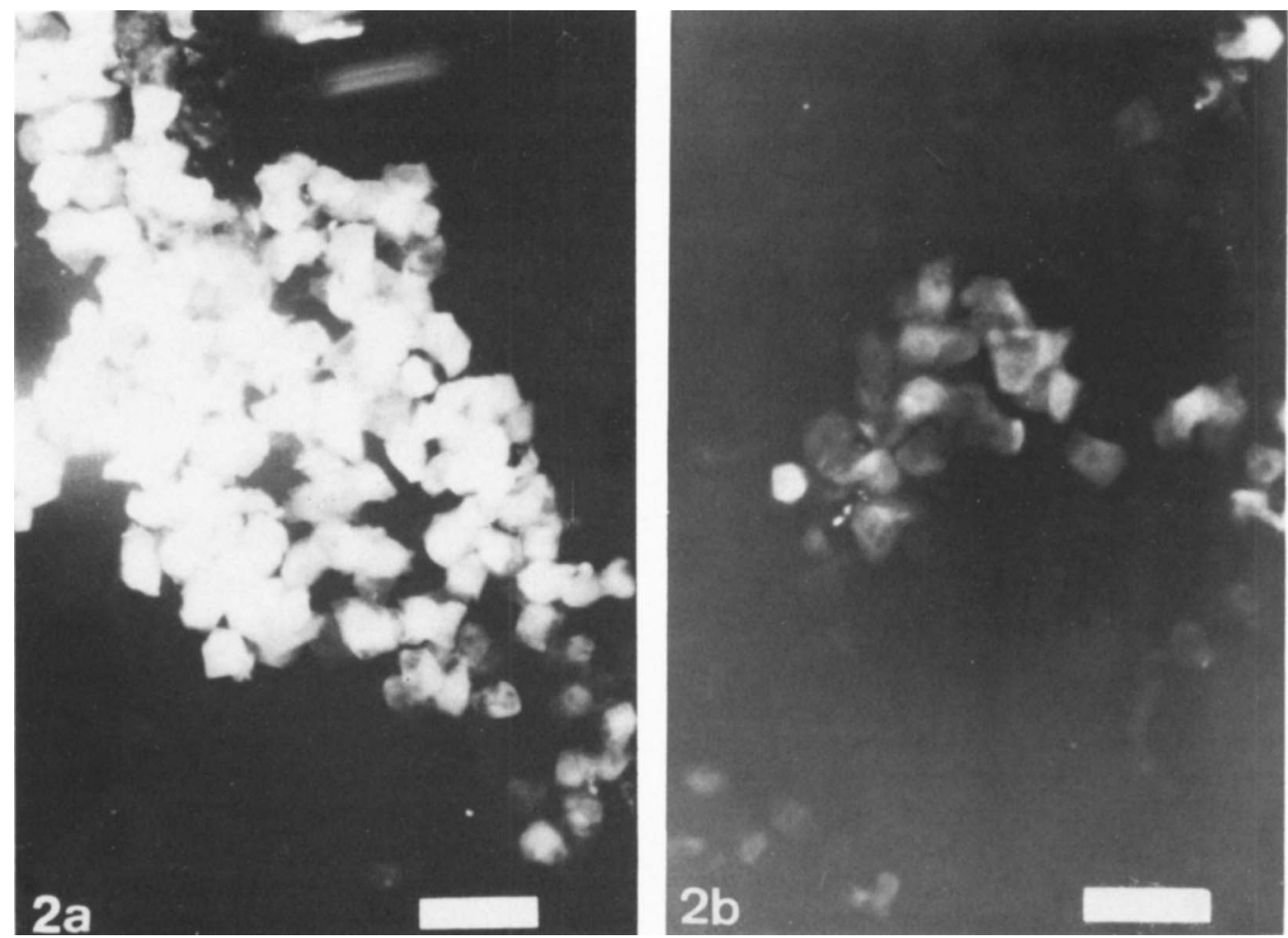

Fig. 2. Indirect fluorescent staining of bovine ruminal epithelial cells treated with (a) the HG of F. necrophorum, and (b) HG preincubated with $\mathrm{HG}$ antiserum. Bar indicates $50 \mu \mathrm{m}$.

nal cells (fig. 2a). The fluorescence was greatly reduced when the $\mathrm{HG}$ was pre-incubated with specific antiserum for $1 \mathrm{~h}$ at $37^{\circ} \mathrm{C}$ before being used to treat the epithelial cells (fig. 2b).

\section{Pretreatment of bovine ruminal cells}

Pretreatment of the bovine ruminal cells with pepsin or trypsin caused a reduction in the number of adherent bacterial cells of about $50 \%$ and $33.3 \%$ respectively (table III) $(\mathrm{p}<0 \cdot 01)$. Treatment with lipase caused no significant reduction.

\section{Discussion}

Bovine ruminal and reticular abscesses and rumenitis are frequently observed in slaughterhouses in Japan and $F$. necrophorum can be isolated from these lesions in heavy and often pure culture (Kanoe et al., 1978, 1984). Adherence of the bacterium to the bovine ruminal mucosa has been recognised as an important early event in infection (Kanoe et al., 1978). Interest has recently focussed on the possible role of bacterial HG in the establishment of infec- tions in man and animals (Atkinson and Trust, 1980; Nagai et al., 1984; Crichton and Walker, $1985)$. In this study, we observed that $F$. necrophorum VPI 2891 adhered well to the membrane of bovine ruminal cells. Adherence was inhibited when the bacteria were pretreated with $\mathrm{HG}$ antiserum. Furthermore, immunofluorescence studies demonstrated that the purified HG readily became bound to the ruminal cell membranes, but the effect was reduced when the $\mathrm{HG}$ was pretreated with $\mathrm{HG}$ antiserum. These observations indicate that fusobacterial cell attachment to bovine ruminal epithelial cells is mediated by HG.

Scanning electronmicroscopy revealed that the microvilli on the ruminal cell membrane did not surround the bacterial cells. This contrasted with the interactions between Yersinia pseudotuberculosis and the Hela cell surface (Brunius and Bölin, 1983 ) and $F$. necrophorum and the Vero cell membrane (Kanoe et al., 1985). Attempts were also made to determine the nature of the HG-binding site on the ruminal cell membrane by the use of enzymes. A reduction of the adherence activity was brought about by pretreatment with pepsin and 
trypsin, but not lipase. This suggests that the HGbinding site on ruminal cells differs from the Escherichia coli type-1 pili-binding site (Salit and Gotschlich, 1977).

\section{REFERENCES}

Atkinson H M, Trust T J 1980 Hemagglutination properties and adherence ability of Aeromonas hydrophila. Infection and Immunity 27:938-946.

Beachey E H 1981 Bacterial adherence; adhesin-receptor interactions mediating the attachment of bacteria to mucosal surfaces. Journal of Infectious Diseases 143:325-345.

Brunius G, Bölin I 1983 Interaction between Yersinia pseudotuberculosis and the HeLa cell surface. Journal of Medical Microbiology 16:245-261.

Burrows M R, Sellwood R, Gibbons R A 1976 Haemagglutinating and adhesive properties associated with the $\mathrm{K} 99$ antigen of bovine strains of Escherichia coli. Journal of General Microbiology 96:269-275.

Crichton P B, Walker J W 1985 Methods for the detection of haemagglutinins in Aeromonas. Journal of Medical Microbiology 19:273-277.

Fader R C, Avots-Avotins A E, Davis C P 1979 Evidence for pilimediated adherence of Klebsiella pneumoniae to rat bladder epithelial cells in vitro. Infection and Immunity 25:729-737.

Kanoe M, Izuchi Y, Toda M 1978 Isolation of Fusobacterium necrophorum from bovine ruminal lesions. Japanese Journal of Veterinary Science 40:275-281.
We thank Dr S. Tanaka, Faculty of Agriculture, Yamaguchi University for guidance in the techniques of scanning electronmicroscopy. This study was supported in part by a grant-in-aid for co-operative research (58360030) from the Ministry of Education, Science and Culture, Japan.

Kanoe M, Nagai S, Toda M 1985 Adherence of Fusobacterium necrophorum to Vero cells. Zentralblatt für Bakteriologie, Mikrobiologie und Hygiene A 260:100-107.

Kanoe M, Nouka K, Toda M 1984 Isolation of obligate anaerobic bacteria from bovine abscesses in sites other than the liver. Journal of Medical Microbiology 18:365-369.

McNeish A S, Turner P, Fleming J, Evans N 1975 Mucosal adherence of human enteropathogenic Escherichia coli. Lancet 2:946-948.

Nagai S, Kanoe M, Toda M 1984 Purification and partial characterization of Fusobacterium necrophorum hemagglutinin. Zentralblatt für Bakteriologie, Mikrobiologie und Hygiene A 258:232-241.

Salit I E, Gotschlich E C 1977 Type 1 Escherichia coli pili: characterization of binding to monkey kidney cells. Journal of Experimental Medicine 146:1182-1194.

Tajima M, Yagishita T, Nunoya T 1985 Ultrastructure of mycoplasmal capsules as revealed by stabilization with antiserum and staining with ruthenium red. Japanese Journal of Veterinary Science 47:217-223.

Wilson M H, Collier A M 1976 Ultrastructural study of Mycoplasma pneumoniae in organ culture. Journal of Bacteriology 125:332-339. 